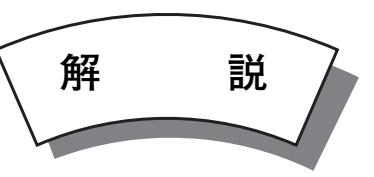

\title{
金属材料のトランススケール複合・機能化に関する基礎研究と社会実装 \\ Fundamental Research on Multi-functional Materials by Atomic to Micron Trans-scale Design and Their Applications
}

\author{
梅田 純子* \\ Junko UMEDA
}

(Received 26 August 2020, Accepted 18 September)

Key Words: Powder Metallurgy, Additive Manufacturing, Direct Bonding, Composites, Rice Husk

\section{1. はじめに}

複合化機構学分野は、接合科学研究所の接合機構部門に 属し、また、工学部応用理工学科機械工学科目㧍よび工学 研究科機械工学専攻の協力講座であることから、同科目・ 専攻に在籍する学生が配属される。本分野の体制は 2020 年 7 月現在、専任教員 3 名、特任助教 1 名、特任研究員 3 名、学生 9 名 (博士後期課程 2 名、博士前期課程 4 名、学 部 4 年生 2 名、特別研究学生 1 名) が在籍している。その うち 3 名が外国籍で、出身国はイラン、夕イ、ガーナと国 際性に富んでいる。2008 年以降、アメリカ、エジプト、オー ストラリア、タイ、台湾、中国、パキスタン、マレーシア から 40 名以上の外国籍の教職員や留学生が在籍した。ま た、大阪大学国際共同研究促進プログラムや広域アジアも のづくり技術・人材高度化拠点形成事業の支援により、国 際協働研究活動をアメリカ、エジプト、オーストラリア、 サウジアラビア、シンガポール、タイ、中国の大学や研究 機関と実施して抢り、研究力の向上のみならず国際社会で 即戦力となり先導できる人材を育むべく連携の強化を行っ ている。他方、本研究所にしては珍しく、2020 年 7 月現在 の女性比率が $31 \%$ (教員 1 名・研究員 1 名・大学院生 3 名) と、本学工学研究科に扔ける女子大学院生や女性教員の比 率 $(16.5 \% 、 9 \%)$ と比較しても非常に高く、男女協働を積極 的に推進している。このように、小規模な研究室において もダイバーシティ・インクルージョンの取り組みは不可欠 となっている。本分野の環境下では、国籍、性差、世代な どの違いによって日常の常識や価值観が異なることを日々 体感し、多様な知見から自然と互いを尊重することを実践 していく中で、個々の可能性を引き出せる研究環境を無意 識のうちに作り出している。このように、多様性からイノ ベーションを生み出し、材料科学の常識を覆した研究から 材料革命を引き起こすことを目指して日々奮闘している。

\section{2. 研究紹介}

本分野では、材料の表界面制御掞よび組織構造制御と多 機能化に着目し、材料・加工プロセスの高度化によるエネ ルギーの効率的利活用と環境低負荷エネルギーの創出 (省・ 創エネルギー）と低炭素化を主題に、材料・加工プロセス の観点から原子〜ナノ〜ミクロンでの階層的トランスス ケール微細構造設計による材料の複合化と高機能化に関す る基礎学理の構築㧍よび応用研究を遂行している。具体的 には、主に 9 つの研究課題に取り組んでいる。

1. 固溶強化原子を利用したチタン焼結材の高強度・高延 性の促進

2. 金属積層造形法 (金属3D プリンティング) によるチタン材 の高次機能化一固溶強化を利用した高強度・高延性の両立

3. 単層カーボンナノチューブの真の機能発現に向けた複 合化材料設計

4. 計算科学による原子スケールでの構造最適化と強度予測

5. 異種材料に扔ける直接接合機構の解明

6. 非食部バイオマスの高度再資源化：も久殼由来多孔質 アモルファス・シリカの生成

7. ケルビンプローブフォース顕微鏡を用いた接合界面で の表面電位差計測とガルバニック腐食機構の解明

8. 粉体プロセスによる完全鉛フリー・快削性高強度黄銅 合金の創製

9. 複合材料に扔ける摩擦摩耗の向上と生体適合性評価 本稿では、紙面の関倸で下記の 4 研究課題を紹介する。

·炭素ナノ粒子の単分散法による金属材料の高強度・高 延性化と表面機能改質

. 原子・ナノ組織構造制御チタン合金の力学機能向上

· 有機一無機および異種金属の直接接合機構の解明

・も2殼由来の非晶質ナノ多孔質構造シリカの多機能性 評価

*大阪大学接合科学研究所 ( $\overline{7} 567-0047$ 大阪府茨木市美穂ヶ丘 11-1)

Joining and Welding Research Institute, Osaka University (11-1, Mihogaoka, Ibaraki, Osaka 567-0047, Japan) 
2.1 炭素ナノ粒子の単分散法による金属材料の高強度・高 延性化と表面機能改質

粉末治金法を基調とした固相焼結技術を用いて、炭 素系ナノ材料である多層カーボンナノチューブ (Carbon Nanotube、CNT）とグラフェンが持つ高剛性・高強度、低 摩擦係数などの特異な性能を金属材料に転写・付与できる 複合化プロセスの研究を遂行している。炭素系ナノ材料は、 優れた多機能性を有する素材と注目されているが、ファン デルワールス引力によるナノ粒子の強固な凝集体を形成 し、炭素系ナノ材料本来の機能が発現せず、特に金属との 複合化では凝集体が材料欠陥となり特性が低下という課題 がある1)。そこで、両性イオン界面活性剤を用いて炭素表 面への+1-電荷付与による電気反発力を利用して凝集現象 を解消し、CNT やグラフェンの単分散化することでバルク 体や粉末の表面への均質被覆製法を確立した。本手法を用 いて、チタン $(\mathrm{Ti})$ やアルミニウム $(\mathrm{Al})$ の高強度・高延性 化を目的に、粉末表面にCNT やグラフェンを均一に被覆 した状態で粉末治金法 (固相製法)により固化して得られ る炭素/金属基ナノコンポジット材料において、炭素粒子 と金属素地の異相界面にナノスケールの超微細針状炭化物 (ナノロッド）を形成し、界面での応力伝達効率向上による 高強度化に成功した。一例として、CNT 分散による純 $\mathrm{Al}$ 材料の高強度・高延性化について説明する。上述した CNT の単分散化手法に加え、ボールミル装置を用いた強塑性加 工 (高歪み加工) 製法の適用により、CNT の完全単分散化 と同時に、純 $\mathrm{Al}$ 粉末内に CNT を均質に分散・分布できる プロセスを構築した。純 $\mathrm{Al}$ 粉末と CNT の混合処理過程に おいて、機械的エネルギーによる $\mathrm{Al} / \mathrm{CNT}$ 複合粉末に塑性 変形を付与することで $\mathrm{Al}$ 粉末を構成する $\alpha-\mathrm{Al}$ 結晶粒界に $\mathrm{CNT}$ を均一分散することで pinning 効果により、 $\alpha-\mathrm{Al}$ 結晶 粒の微細化 $(2.2 \mu \mathrm{m} \rightarrow 0.63 \mu \mathrm{m})$ に寄与し、CNT の分断によ るアスペクト比 $(55 \rightarrow 6.5)$ の制御を可能とした。また、混 合処理過程での自然酸化現象に由来する酸素を活用し、固 相焼結過程において酸素原子の固溶反応により生成する $\mathrm{Al}_{2} \mathrm{O}_{3}$ ナノ粒子の合成と添加した CNT が均一単分散したハ イブリッドナノコンポジットの作製に成功した。本材料の 引張試験の結果、引張強さ $540 \mathrm{MPa}$ 、破断伸び $10 \sim 12 \%$ を維持した。これは、純 $\mathrm{Al}$ 材に対して約 3 倍の高強度化を 達成すると同時に、工業用金属素材として十分に利用可能 な高延性を有することを確認した。このような特異な力学 特性を解明すべく、SEM 内引張試験その場観察と高分解能 TEM 観察により、その強化機構を定量的に考察した。その 解析結果を Fig. 1 に示す。本 $\mathrm{Al} / \mathrm{CNT}$ 複合材料は複雑な強 化因子を有し、 $\alpha-\mathrm{Al}$ 結晶粒の微細化効果、その粒成長抑制 のための CNT の粒界 pinning 効果および $\mathrm{Al}$ 素地との完全 反応によりその場合成された $\gamma-\mathrm{Al}_{2} \mathrm{O}_{3}$ ナノ粒子 pinning 効果、 アスペクト比が異なる $\mathrm{CNT}$ 分散強化、界面での $\gamma-\mathrm{Al}_{2} \mathrm{O}_{3}$ ナ ノ粒子による Load-transfer 効果により高強度と高延性を同 時に発現した。次に、 $\mathrm{Al} / \mathrm{CNT}$ 複合材の引張強さと伸びの相
関を Fig. 2 に示す。本製法を適用した材料（丸）は、従来 の機械的混合法により作製した材料やセラミックス粒子添 加材料と比較して、両特性は大きく向上した。従来材では CNT 凝集体が残存するために強度改善効果が十分に発現し ないが、本製法によって CNT を単分散化することで高強度. 高延性バランスを達成した ${ }^{2-7)}$ 。

次に、CNTの優れたベアリング効果に着目した純チタン の摩擦摺動特性向上に関して述べる。既往研究において、 耐腐食性に劣る軽金属素材表面にCNT を直接被膜し、そ の摩擦摺動特性を評価した報告例は少ない。一方、摺動部 材への CNT 被覆技術に関しては、CNT 表面処理剤塗布や CNT 膜生成が開発されているが、工程が多岐に渡る上に、 耐熱性や熱伝導性に劣り、焼きつきを防ぐために充填剤や 固体潤滑剂が必要になるなどの問題点がある。そこで、簡 便な塗布プロセスとして、チタンの酸化防止の観点から非 水系溶媒とした単分散 CNT 分散溶液に $\mathrm{Ti}$ 基材を浸漬し、 基材表面にCNT を完全に分散したネットワーク状の被膜を

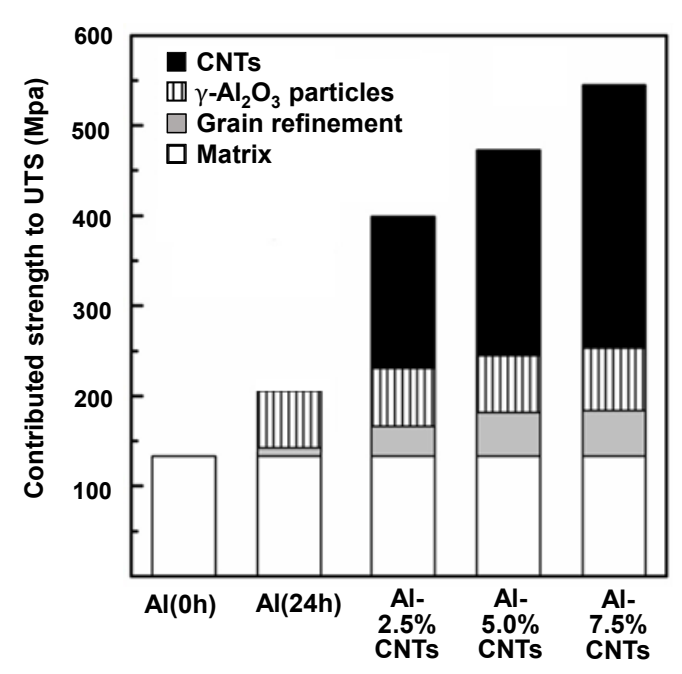

Fig. 1 Strengthening factors contribution to UTS increment of Al-CNTs materials with different CNTs content compared to experimental data.

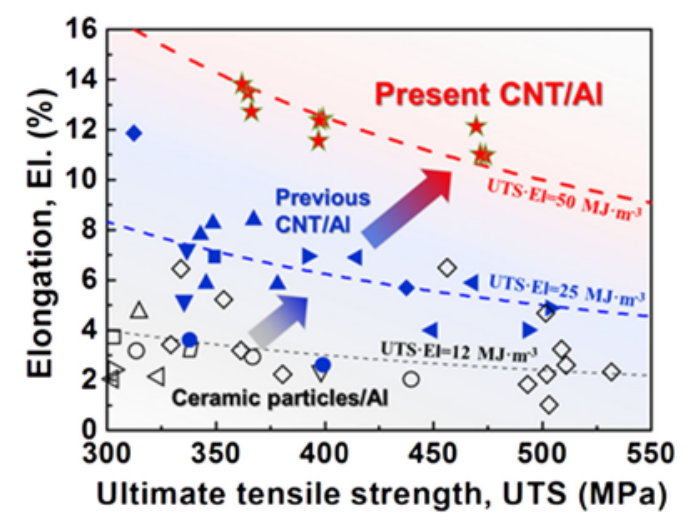

Fig. 2 Tensile properties of Al materials reinforced by various ceramic particles/Al (open symbols), by previous CNTs/Al study (closed symbols), and the present CNTs/Al study $(\star)$. 
直接密着形成させた。CNTと $\mathrm{Ti}$ 基材の密着性を向上すべ く、 $\mathrm{Ti} へ の$ 炭素原子の固溶限を考慮した真空熱処理を適用 することで、CNT 由来炭素原子が $\mathrm{Ti}$ 結晶格子内に侵入固 溶・拡散した際、固溶限を超えた炭素分と $\mathrm{Ti}$ の反応により 生成する炭化チタニウム（ $\mathrm{TiC}$ ) 層を介して CNT と $\mathrm{Ti}$ 基材 の治金的結合性を確認し、直接固相接合法を確立した。ま た、大気環境下で摩擦摩耗試験によるCNT 被覆の密着力 と CNTのベアリング効果を評価した結果 (Fig. 3)、CNTnet 形成による摩擦係数の低位安定化と耐摩耗性の顕著な改 善向上を実現した ${ }^{8)}$ 。さらに、本研究所の共同利用・共同 研究員制度を活用して北海道大学歯学部および同大学歯学 部病院と連携し、CNT 被覆 $\mathrm{Ti}$ 基材を用いて骨芽細胞の形成・ 成長過程に及ぼす CNT 被膜最表面での幾何学的形状因子 の影響について、in-vitro 試験を実施して骨芽細胞の繁殖状 態の解析およびラットの頭蓋部への埋め込み試験（in-vivo） による性能検証を行った。その結果、CNTの全長や直径の 影響に比べて、CNT 被膜内に形成される CNT 間距離 (粗 密度合い) が数 $\mu \mathrm{m}$ を超える状態では細胞同士間での伝達 · 連結・成長が困難となり、細胞が死滅に至ることも観察し、 空間長さが骨芽細胞の成長に対してょり顕著に影響するこ とを確認した ${ }^{9), 10) 。 ~}$

このように炭素ナノ粒子の完全なる均一単分散化プロセ スと、それを活用した各種金属材料の高次多機能化の実証 などを通じて、炭素ナノ粒子と金属のハイブリッド化によ る新規機能発現を可能とした。

2.2 原子・ナノ組織構造制御チタン合金の力学機能向上

汎用チタン合金におけるレアメタル元素添加依存から脱 却すべく、資源的に豊富で極めて廉価な軽元素に着目し、 粉末治金プロセスによるチタン材の高強度・高延性化に関 する基礎的研究および実用化研究を推進している。航空 機部材や医療デバイスなどの高付加価值製品へ適用される チタン材は、䨌囲気中の空気に由来する酸素や窒素が活性 な $\mathrm{Ti}$ 粉末と反応し、チタンの延性低下を誘発するといっ た課題が存在する。古くから、酸素・窒素・水素は金属材 料の脆化を招く負の材料因子と位置付けられており、工業 用純チタンにおいても米国の ASTM 規格や JIS 規格では各 元素の含有量の上限を、酸素量 ; 0.4 mass\%、窒素量 ; 0.05 mass $\%$ 、水素量 : 0.015 mass $\%$ と規定している ${ }^{11), 12) 。 こ の 上 ~}$
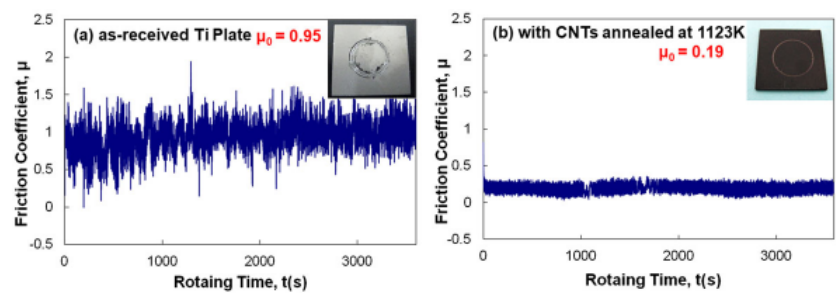

Fig. 3 Friction coefficient changes of (a) as-received Ti plate and (b) with CNTs film after annealing at $1123 \mathrm{~K}$ by employing a SUS304 stainless steel ball as counter material in ball-on-disk wear test under dry condition.
限值を超える高濃度の成分を含む場合、強度や硬度は増加 する一方で材料の伸び值が著しく激減し、実用素材料とし ての利用は困難であると認識されている。また、酸素や窒 素を含む化合物相は、熱力学的に安定なために熱処理によ る還元分解は難しく、既往研究においては熱分解の適用は 不可能とされてきた。本分野では、酸素・窒素・水素を第 2 添加元素として、非常識とも言える各々高濃度含有する 組成の $\mathrm{Ti}$ 粉末を用いた固相焼結法および金属積層造形法に おいて、延性低下を伴うことなく、高強度・高延性の同時 発現を可能とする新たな合金創製技術の開発を目指してい る。

まず、固相焼結法による微量酸素添加 Ti 焼結材について 説明する。純 $\mathrm{Ti}$ 粉末と酸素供給源となる $\mathrm{TiO}_{2}$ 粒子の混合 粉末を固相焼結した際、 $\mathrm{TiO}_{2}$ の熱分解挙動と解離した酸素 原子の $\alpha-\mathrm{Ti}$ 結晶 (hep 構造) 内への侵入固溶による $\mathrm{c}$ 軸方 向に $\alpha-\mathrm{Ti}$ 結晶格子の伸長に伴う歪み場形成していることが 明らかとなった。その結果、純 $\mathrm{Ti}$ 材と比較して 3 倍以上の 引張強さと Ti64 合金の特性を超える高疲労強度を発現した

(Fig. 4)。強化機構が酸素原子の固溶強化に起因すること を実証すべく、古典強化理論に基づく Labusch model を用 いて酸素固溶量と耐力増加量の関係を整理した結果、引張 試験による実験值と理論值の定量的な一致を示した。他方、 破断伸びは、酸素量が約 0.8 mass\% であっても $25 \sim 28 \%$ の高い伸びを有しており、それを超える酸素量においても $20 \%$ を超える延性を有した。結晶粒界近傍に酸化物 $\left(\mathrm{TiO}_{2} /\right.$ TiO）は生成せず、酸素が原子状態で $\alpha-\mathrm{Ti}$ 結晶内に均一固 溶することにより延性低下を抑制しつつ、固溶強化による 高強度特性を維持できる特異な力学特性を有することを明

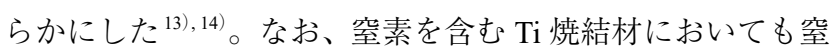
素原子の固溶現象を促すことによって、窒素 $0.52 \mathrm{mass} \%$ を 含む $\mathrm{Ti}$ 焼結材では耐力值 $947 \mathrm{MPa}$ に達しており、窒素固溶 強化によって純 $\mathrm{Ti}$ 粉末焼結材の耐力值 $412 \mathrm{MPa}$ を 2 倍以上 の増加を示した。加えて、破断伸び值は $30 \%$ 以上を呈して、 十分な延性を保持している。JIS で規定されている純 Ti 材

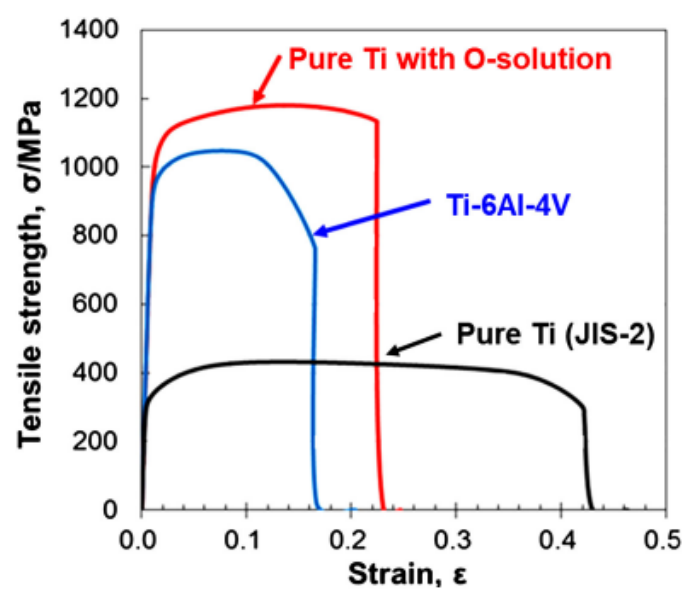

Fig. 4 Tensile properties of SPSed Ti-O, Ti-6Al-4V and pure Ti materials. 
の窒素含有量 $(<0.05$ mass\%) の 10 倍以上含有するにも関わ らず、延性低下を誘発しない特異な力学特性を発現するこ とを実証した ${ }^{15-17)}$ 。続いて、中間素材である廉価な水素化 チタン $\left(\mathrm{TiH}_{2}\right)$ 粉末を直接原料とした純チタン材創製に関し て説明する。チタンにおいても水素は脆化を誘発する成分 である一方で、 $\beta$ 相安定化元素であることに着目し、高濃 度の水素含有 $\mathrm{Ti}$ 焼結材に対して熱間塑性加工を施した。押 出加工の冷却過程での $\beta \rightarrow \alpha$ 相変態において、Burger's の 結晶方位関係に基づいて高剛性を示す $<0001>\alpha$ 集合組織の 形成を試みた結果、水素成分を 0.33 mass\% 含有することで 押出方向と平行に繊維状に配列した $\mathrm{B} / \mathrm{T}$-texture、六方晶格 子の $\mathrm{c}$ 軸が押出方向と平行に配列した〈0001〉集合組織を 有し、微細な結晶粒組織を呈し、122 GPaの高剛性を達成 した。同時に、伸び值の低下を伴わずに耐力值の向上を実 現した。また、SEM 内その場観察を行った結果、Ti 結晶粒 を分断するように析出した微細な $\mathrm{TiH}_{2}$ 化合物相の分散が変 形双晶の局所的に発生し、その進展と粗大化を抑制したこ とで、試料全体に大きな均一変形が生じるという事実を見 出した (Fig. 5)。このような特異な集合組織の形成は、熱 間押出加工時に水素が $\beta$ 相安定化因子として作用すること で、 $\mathrm{Ti} の \beta$ 変態温度が低下して $\beta$ 単相域もしくは $\alpha+\beta$ 共 存域からの加工が安定化することに起因することを明らか にした ${ }^{18), 19) 。 ~}$

続いて、固相焼結法の研究成果に基づき金属積層造形法 の一つである選択的レーザ溶融法 (Selective Laser Melting、 SLM) へ展開し、積層造形過程での軽元素の振舞いと強化 機構に係る研究を進めている。本稿では窒素を対象に行っ た成果を述べる。JIS 規格上限值 $0.05 \mathrm{mass} \%$ を遥かに上回 る高濃度窒素含有純チタン粉末として、窒素ガス䨌囲気中 で純 Ti 球状粉末を熱処理による JIS 規格の上限值 10 倍以 上となるコアシェル構造の窒素 $0.3 \sim 0.7 \mathrm{mass} \%$ 含有 $\mathrm{Ti}$ 粉 末を作製した。これを出発原料として SLM 法により $\mathrm{Ti}$ 積 層造形体を作製した結果、積層造形過程で窒化被膜は分解 し、解離した窒素成分は $\alpha-T i$ 結晶粒内に固溶することで 主に $\mathrm{c}$ 軸方向への結晶格子が拡張した。その引張特性を評 価した結果 (Fig. 6)、0.32 mass\% 窒素含有積層造形体の引

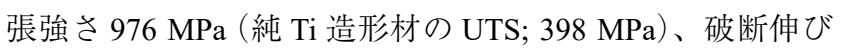
值は $21.7 \%$ (同伸び值；18.9\%）となり、相反関係にある強 度と延性を高い水準で両立できる特異な力学挙動を実現し た。組織観察の結果、窒素成分の粒界偏析や濃化は見られ ず、SLM 過程でのレーザ照射により溶融した Ti 粉末が急 速な凝固現象（冷却速度 $10^{4} \sim 10^{7} \mathrm{~K} /$ 秒）を活用した窒素原 子均一固溶に関する合金設計の有効性を実証した。他方、 窒素量が 0.7 mass\%に増大した場合、マルテンサイト相の 粒界近傍に窒素原子が濃化するため、引張試験では弾性域 での破断により破断伸び值は $0 \%$ を呈した ${ }^{20), 21) 。 ~}$

以上のように、高い信頼性のもとで廉価な軽元素を高濃 度含有 $\mathrm{Ti}$ 粉末材から、固相焼結法および金属積層造形法に おいて、汎用チタン合金の特性を凌駕する高強度・高延性

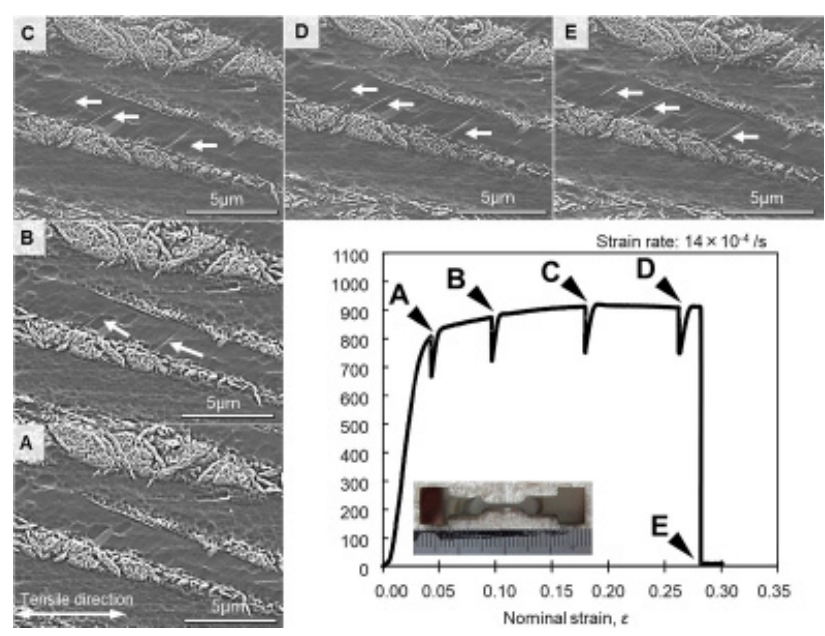

Fig. 5 Stress-strain curve and in-situ SEM microstructures of extruded $\mathrm{TiH}_{2}$ powder materials during tensile testing. The arrows indicate deformation twins.

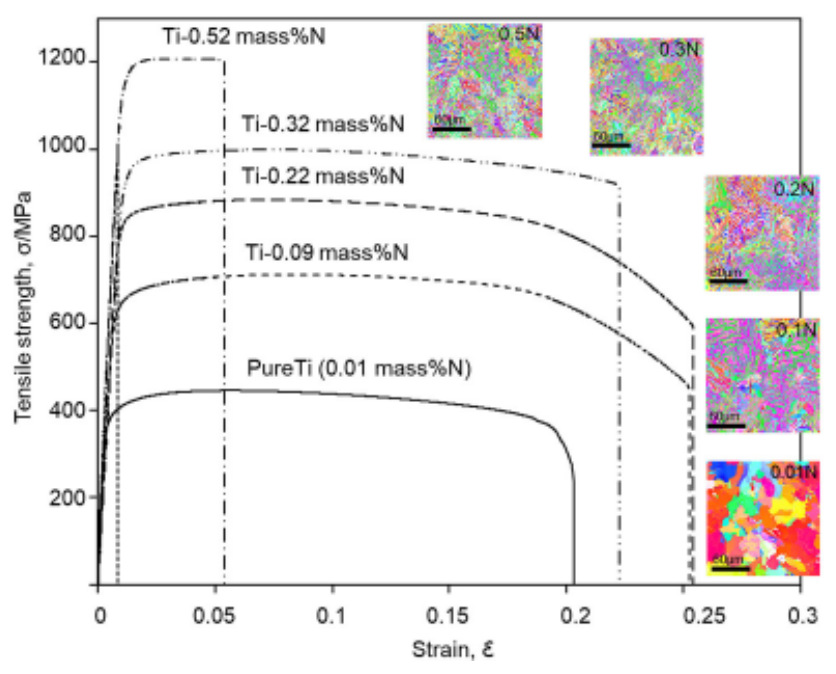

Fig. 6 Stress-strain curve in tensile test at room temperature and inverse pole figure maps of SLMed Ti-N materials with different nitrogen solution contents.

化を可能とする新規プロセスを示し、引き続き従来の合金・ プロセス設計の限界を超える革新的製法の構築を目指して い。

\section{3 有機 - 無機および異種金属の直接接合機構の解明}

構造用素材として比剛性・比強度に優れた軽量素材で ある炭素繊維強化樹脂 (Carbon Fiber Reinforced Plastics、 CFRP）と工業用金属材料による複合材料の実用化が急速 に進んでいる。CFRPの素地となる樹脂は熱硬化性から熱 可塑性に替わり、その結果、高速スタンピング成形による CFRP 製複雑形状部品の創製が可能となり、また素材のリ サイクル向上 (=コスト削減)にも寄与できることが明ら かとなっている22)。他方、接合・接着などの 2 次加工性が CFRP 素材に対して要求される。接着性能や強度はCFRP 素材の表面性状や物性に依存する他、使用環境によっては 
接着剂の性能劣化に起因して接合強度や部材寿命が CFRP 製構造体の性能低下を誘発するといっても過言ではない。 そこで本分野では、性能劣化が懸念される接着剤を一切使 用せずに、母材と同等以上の力学特性および機能を有する CFRP 接合部材の創製に資する高信頼性接合技術の基礎研 究を進めている。具体的には、CFRP を構成する熱可塑性樹 脂が $\mathrm{C}=\mathrm{O}$ 二重結合を含むカルボニル基を有することに着目 し、汎用性の高い温間プレス成形法を用い、加熱・加圧条件 下での樹脂と純 $\mathrm{Ti}$ 材との反応に基づく、 $\mathrm{Ti}$ 側への酸素原子 固溶による $\mathrm{C}=\mathrm{O}$ の還元離脱と有機金属化合物の生成による 完全接合を試みている。樹脂には $\mathrm{C}=\mathrm{O}$ 結合を有するポリア ミド $66\left(\mathrm{PA} 66 、\left\{\mathrm{CO}-\left(\mathrm{CH}_{2}\right)_{4}-\mathrm{CO}-\mathrm{NH}\left(\mathrm{CH}_{2}\right)_{6}-\mathrm{NH}\right\} \mathrm{n}\right)$ と、 $\mathrm{C}=\mathrm{O}$ 結合を有しないポリスチレン ( $\left.\mathrm{PS},\left\{\mathrm{CH}_{2}-\mathrm{CH}-\left(\mathrm{C}_{6} \mathrm{H}_{5}\right)\right\} \mathrm{n}\right)$ を選 択して Ti 板材との接合体を作製した。加熱温度と接合強度 (引張剪断力) の相関について調査した結果を Fig. 7 に示 す。両樹脂材の融点近傍において界面強度は急激に増大し、 PA66のみが高い接合強度を呈した。TEMによる組織観察 の結果、 $\mathrm{Ti}$ 試料側の接合界面に酸素が $30 \sim 50 \mathrm{~nm}$ の濃化 領域が存在していること観察された。純チタンの酸素固溶 限は 34 at.\%と大きいことから、PA66に含まれる C=O二 重結合が分解して酸素原子が乘離し、Ti 表層に化学的に安 定した状態で接合したと考えられる。このように $\mathrm{C}=\mathrm{O}$ 結 合が樹脂と金属の直接接合機構に不可欠であることが示差 された ${ }^{23)}$ 。

次に、純 $\mathrm{Ti}$ と $\mathrm{Mg}$ 合金 (Mg-Al 系) の異種金属を対象に、 直接固相加圧接合プロセスを検証した。加熱・加圧下での 固相接合過程における界面反応機構を解析した結果、接合 温度を $\mathrm{Mg}$ 合金の共晶点未満の温度域とした試料において、 $\mathrm{Mg}$ 合金中の $\mathrm{Al}$ 含有量の増加および接合時間の増大に伴い 界面の接合強度が増加した。また、 $\mathrm{Mg}$ 合金側の破断面に は river pattern を伴う良好な接合状態を示す変形領域を確認 した。接合界面の TEM 観察を行った結果、各試料表面に 自然形成された酸化膜 $\left(\mathrm{MgO}\right.$ と $\left.\mathrm{TiO}_{2}\right)$ は接合界面にも観察

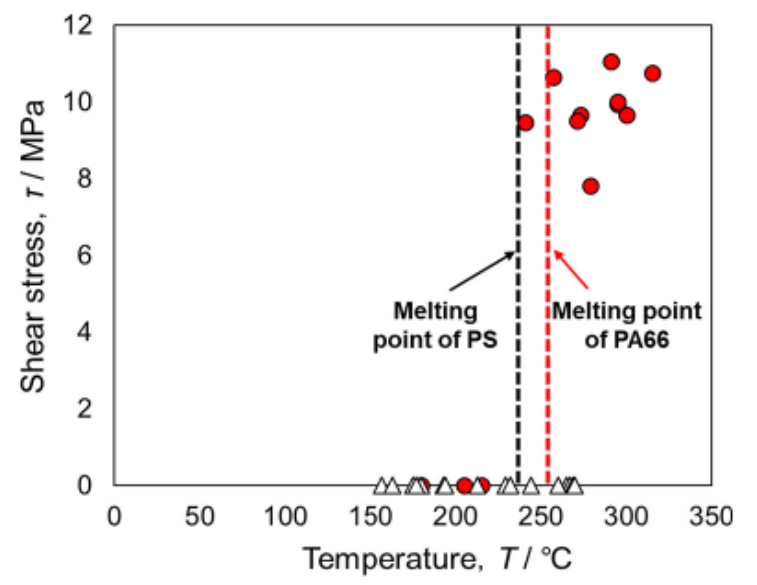

Fig. 7 Shear bonding strength of dissimilar materials between pure Ti plate and PA66 and PS plastic materials prepared by changing bonding temperature.
されるが、高い接合強度を有する試料では、 $\mathrm{Mg}$ 合金に含 まれる $\mathrm{Al}$ 成分に由来する厚さ $30 \sim 40 \mathrm{~nm}$ の $\mathrm{Al}$ 拡散層の 存在を確認した（Fig. 8)。さらに、ネットワーク状の $\beta$ 相 $\left(\mathrm{Mg}_{17} \mathrm{Al}_{12}\right)$ が分散しており、その分散面積率の増加により 接合領域が増大した結果、接合強度の増加傾向が生じたと 推察される24),25)。

以上のように、異種材料における接合界面の構造や物性 の理解を通じて接合体の特性や機能を把握し、優れた耐久 性や信頼性を有する新たな直接接合プロセスを確立して異 材接合強度の向上を目指す。

\section{4 もみ殼由来の非晶質ナノ多孔質構造シリカの多機能性 評価}

日本を含めて世界中で量・質ともに安定して発生する農 業廃棄物のもみ殼を活用し、3 次元ナノ空孔を有するもみ 殼由来非晶質シリカ（Fig. 9）を、安全かつ経済性に優れた 機能性素材として再生する実用化研究を実施している。既 往研究では、もみ殼に含まれる炭水化物を熱源に利用する バイオマスプロセスの開発が主流であったが、本研究にお

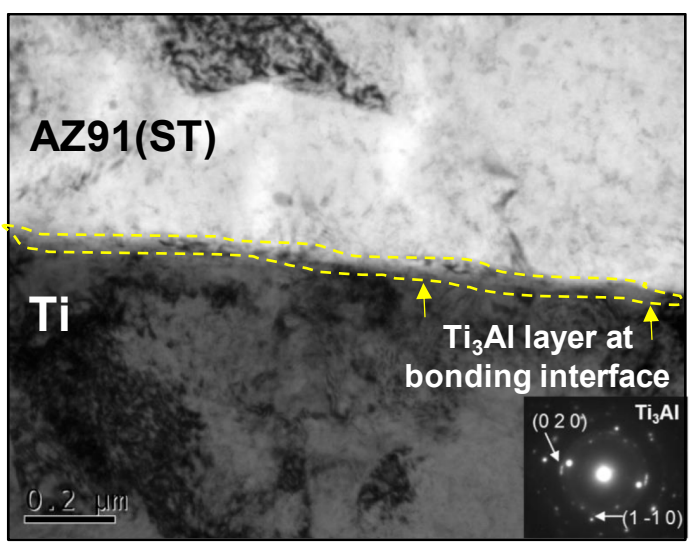

Fig. 8 TEM observation at bonding interface of pure Ti/AZ91 bonded at $748 \mathrm{~K}$ for $1 \mathrm{~h}$ with $10 \mathrm{MPa}$ applied pressure.
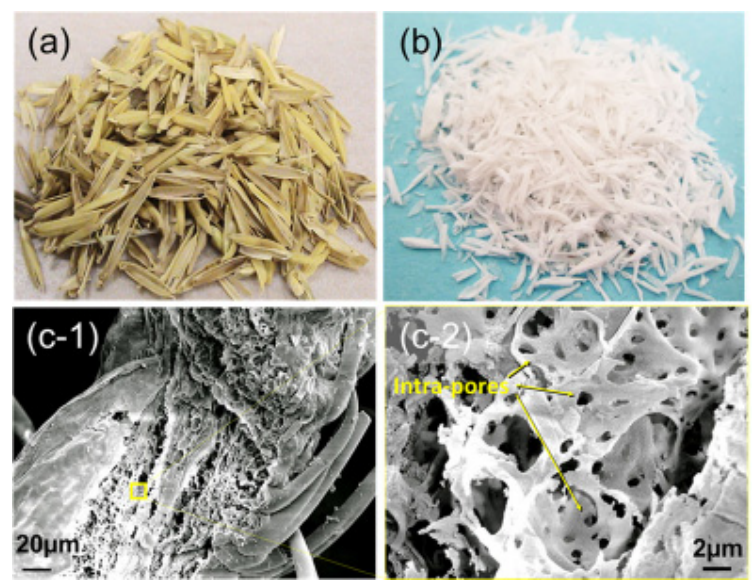

Fig. 9 Appearances of (a) rice husk as raw material and (b) high purity amorphous silica from rice husks. SEM images of (c-1) cross section view of rice husk ash and (c-2) high magnification of (c-1). 
いては、植物由来の 3 次元の骨格構造を有する非晶質シリ カ成分に着目し、これを非晶質の状態で高純度なナノ多孔 質構造体シリカとして抽出・生成するプロセス研究である。 もみ殼は、焼成過程においてシリカの結晶化が進行して発 癌性物質である結晶性シリカに変化することが既往研究に より報告されている。本分野では、もみ殼に含まれる土壤 由来の微量アルカリ金属成分 $(\mathrm{Mg} 、 \mathrm{~K} 、 \mathrm{Ca}$ など $)$ とシリカ の共晶反応により、低温で局所的に溶融することでシリカ の結晶化が進行する現象を解明した。本結果に基づき、上 記の微量アルカリ金属成分を完全除去すべく、有機酸水溶 液を用いたキレート反応に基づくアルカリ金属錯体形成と 系外排出に関する新たな手法を確立した結果、純度 $99.5 \%$ 以上の非晶質ナノ多孔質構造シリカの生成に成功した ${ }^{26)}$ 。 また本製法は、塩酸や硫酸などの強酸溶液を使用しない点 においても環境負荷が少ない。そこで、ナノ構造体シリカ の高い反応活性を活用し、高機能性素材としての実用化研 究を実施している。一例として、セメントに添加すること で短時間での緻密化を可能とするコンクリート素材の高強

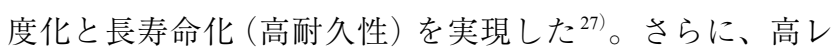
ベル放射性廃棄物処分施設では多層バリア処理した廃棄物 を埋設する際のコンクリート壁からの強アルカリ水が多層 バリア層を破壊する問題に対して、フィールド試験に開発 素材を投入し、亀裂部への素材の注入性や国際原子力機関 (IAEA) が要求する弱アルカリ性 $(\mathrm{pH}<11)$ の達成による耐 バリア性能を検証した。その結果、現行のセメント材料を 使用した供試材は、試験開始後約 1,200 日で $\mathrm{pH}$ 值が 11 付 近に低下するが、もみ殼由来シリカ微粒子を添加した供試 材は、試験開始 14 日以内で $\mathrm{pH} 10.5$ まで低減し、世界最高 水準の特性を最短期間で発現した (Fig. 10)。これは、も み殼由来の多孔質構造と非晶質構造に基づく高い反応活性 が、セメント中の $\mathrm{Ca}$ 成分ともみ殼由来シリカのポゾラン 反応過程における $\mathrm{Ca}$ イオンの吸着性向上と水和物生成に よる緻密化が促進した結果、未反応のアルカリ成分が減少 することによりコンクリート内の $\mathrm{pH}$ 值の急速な低減と強

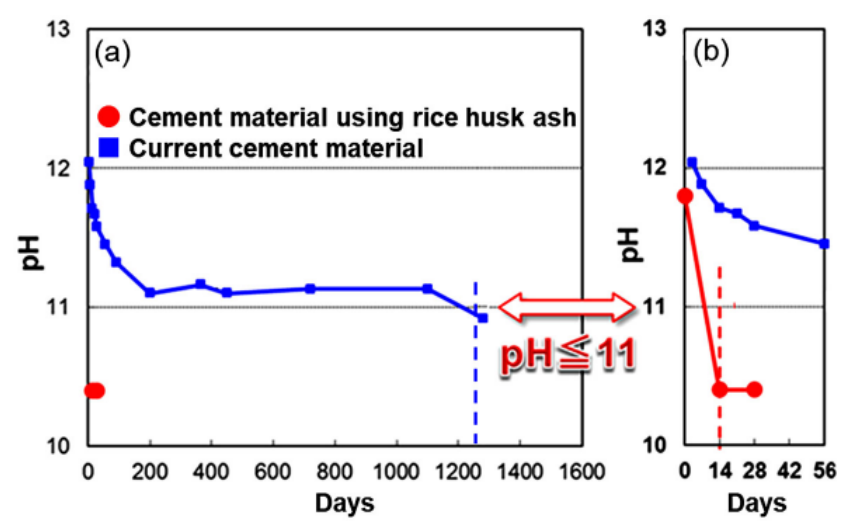

Fig. $10 \mathrm{pH}$ value evaluation of cement materials using rice husk ash compared to the current cement material. (a) total period and (b) initial period of (a).
度向上に寄与した ${ }^{28)}$ 。

このように、もみ殼由来の非晶質ナノ多孔質構造シリカ の多機能性を活用して新たな複合化プロセスの基礎を確立 しつつあり、世界中で要望されている高レベル放射性廃棄 物の地層処分施設の建設に資する革新的な高強度 · 弱アル カリ性セメント素材の創製に向けて、産学官連携による研 究を継続している。

\section{3. おわりに}

以上のように、本分野の研究活動の一部を紹介した。研 究室の HP (http://www.jwri.osaka-u.ac.jp/ dpt6/) を開設して おり、研究活動のみならず、日常の様子も紹介している。 今後も、科学技術の発展を担う学生らと共に、産業界が直 面する接合科学に係る課題に対して、材料科学の観点から 組織構造制御を利用した新奇な高次機能性材料創製の基礎 研究と産学共創による実用化開発研究に、研究室一丸と なって取り組んでいく所存である。

\section{謝 辞}

本研究の一部は、国立研究開発法人科学技術振興機構 (JST) 未来社会創造事業・探索加速型「地球規模課題であ る低炭素社会の実現」、内閣府総合科学技術・イノベーショ ン会議の戦略的イノベーション創造プログラム (SIP)「統合 型材料開発システムによるマテリアル革命」（管理法人： JST)、科学研究費補助金 $(16 H 02408 、 20 K 05155)$ 、公益財団 法人天田財団、国立研究開発法人農業 · 食品産業技術研究 総合機構生物系特定産業技術研究支援センター「革新的技 術創造促進事業 (異分野融合共同研究) 」、大阪大学国際共 同研究促進プログラム、広域アジアものづくり技術・人材 高度化拠点形成事業の支援により行われた。また、複合化 機構学分野の教職員、学生および卒業生に深く感謝の意を 表します。

\section{参考文献}

1) S.R. Bakshi, D. Lahiri and A. Agarwal: "Carbon nanotube reinforced metal matrix composites - a review”, Journal of International Materials Reviews 55 (2010), 41-64.

2) B. Chen, X.Y. Zhou, B. Zhang, K. Kondoh, J.S. Li and M. Qian: "Microstructure, tensile properties and deformation behaviors of aluminium metal matrix composites co-reinforced by ex-situ carbon nanotubes and in-situ alumina nanoparticles", Materials Science and Engineering A 795 (2020), 139930.

3) B. Chen, K. Kondoh, J. Umeda, S. Li, L. Jia and J. Li: "Interfacial in-situ $\mathrm{Al}_{2} \mathrm{O}_{3}$ nanoparticles enhance load transfer in carbon nanotube (CNT) -reinforced aluminum matrix composites", Journal of Alloys and Compounds 789 (2019), 25-29.

4) B. Chen, K. Kondoh, J.S. Li and M. Qian: "Extraordinary reinforcing effect of carbon nanotubes in aluminium matrix composites assisted by in-situ alumina nanoparticles", Composites Part B 183 (2020), 107691. 
5) B. Chen, J. Shen, X. Ye, H. Imai, J. Umeda, M. Takahashi and K. Kondoh: "Solid-state interfacial reaction and load transfer efficiency in carbon nanotubes (CNTs) -reinforced aluminum matrix composites", Carbon 114 (2017), 198-208.

6) B. Chen and K. Kondoh: "Sintering Behaviors of Carbon Nanotubes-Aluminum Composite Powders", Metals 6-9 (2016), 213.

7) B. Chen, S. Li, H. Imai, L. Jia, J. Umeda, M. Takahashi and K. Kondoh: "Load transfer strengthening in carbon nanotubes reinforced metal matrix composites via in-situ tensile tests", Composites Science and Technology 113 (2015), 1-8.

8) J. Umeda, B. Fugetsu, E. Nishida, H. Miyaji and K. Kondoh: "Friction behavior of network-structured CNT coating on pure titanium plate", Applied Surface Science 357 (2015), 721-727.

9) H. Miyaji, S. Murakami, E. Nishida, T. Akasaka, B. Fugetsu, J. Umeda, K. Kondoh, T. Iizuka and T. Sugaya: "Evaluation of Tissue Behavior on Three-dimensional Collagen Scaffold Coated with Carbon Nanotubes and $\beta$-tricalcium Phosphate Nanoparticles", Journal of Oral Tissue Engineering 15-3 (2018), 123-130.

10) E. Nishida, H. Miyaji, J. Umeda, K. Kondoh, H. Takita, I. Kanayama, S. Tanaka, A. Kato, B. Fugetsu, T. Akasaka and M. Kawanami: "Biological Response to Nanostructure of Carbon Nanotube/titanium Composite Surfaces", Nano Biomedicine 7-1 (2015), 11-20.

11) ASTM B348 / B348M:2019, Standard Specification for Titanium and Titanium Alloy Bars and Billets.

12) JIS H 4600:2012, Titanium and titanium alloys - Sheets, plates and strips.

13) S. Kariya, M. Fukuo, J. Umeda and K. Kondoh: "Quantitative analysis on light elements solution strengthening in pure titanium sintered materials by Labusch model using experimental data", Materials Transactions 60-2 (2019), 263-268.

14）刈屋翔太, 梅田純子, Ma Qian, 近藤勝義 : 急冷処理による酸 素過剰添加チタン材の延性向上とその機構解明, 金属学会誌 82-10 (2018), 390-395.

15) J. Umeda, H. Ishizaka, S. Li, A. Alhazaa, and K. Kondoh: "Comparison study on mechanical properties of powder metallurgy titanium materials with nitrogen solutes and TiN dispersoids", Journal of Alloys and Compounds 846 (2020), 156455.

16) A. Issariyapat, P. Visuttipitukul, T. Song, J. Umeda, Q. Ma and K. Kondoh : "Strength-ductility improvement of extruded Ti(N) materials using pure Ti powder with high nitrogen solution", Materials Science and Engineering A 779 (2020), 139136.

17) Y. Yamabe, J. Umeda, H. Imai and K. Kondoh: "Tribological
Property of $\alpha$ - Pure Titanium Strengthened by Nitrogen SolidSolution", Materials Transactions, 59-1 (2018), 61-65.

18) J. Umeda, T. Mimoto, H. Imai and K. Kondoh: "Powder Forming Process from Machined Titanium Chips via Heat Treatment in Hydrogen Atmosphere", Materials Transactions 58-12 (2017), 1702-1707.

19) T. Mimoto, J. Umeda and K. Kondoh: "Strengthening behaviour and mechanisms of extruded powder metallurgy pure Ti materials reinforced with ubiquitous light elements", Powder Metallurgy 59-3 (2016), 223-228.

20) K. Kondoh, A. Issariyapat, J. Umeda and P. Visuttipitukul: "Selective laser-melted titanium materials with nitrogen solid solutions for balanced strength and ductility", Materials Science \& Engineering A 790 (2020), 139641.

21） A. Issariyapat, 近藤勝義, P. Visuttipitukul, T. Song, M. Qian, 梅田純子：“窒素含有チタン粉末の特性と積層造形体におけ る力学特性”, スマートプロセス学会誌 8-3 (2019), 95-101.

22) K.K. Chawla, Composite Materials, Science and Engineering, Springer, New York, 1998.

23) K. Kondoh and J. Umeda: "C-O bond enhancing direct bonding strength between plastic and pure titanium", Materials Letters 211 (2018), 331-334.

24) P. Pripanapong, J. Umeda, H. Imai, M. Takahashi and K. Kondoh: "Bonding mechanism of Ti/AZ80 dissimilar materials fabricated by spark plasma sintering", Journal of Multidisciplinary Engineering Science Studies 2-10 (2016), 1009-1013.

25) J. Umeda, N. Nakanishi, K. Kondoh and H. Imai: "Surface potential analysis on initial galvanic corrosion of $\mathrm{Ti} / \mathrm{Mg}-\mathrm{Al}$ dissimilar material", Materials Chemistry and Physics 179 (2016), 5-9.

26) J. Umeda and K. Kondoh: "High-purification of amorphous silica originated from rice husks by combination of polysaccharide hydrolysis and metallic impurities removal", Industrial Crops and Products 32 (2010), 539-544.

27）梅田純子, 高田龍一, 道浦吉貞, 近藤勝義：“農作物非食部 バイオマスから高純度非晶質シリカの抽出プロセスとコンク リート用混和材としての利活用”, スマートプロセス学会誌 3-5 (2014), 317-321.

28）梅田純子，藤井寛子，近藤勝義：“焼成籾殼中の脆性炭化物を 利用した非晶質シリカ微粒子の生成プロセス”, スマートプロ セス学会誌 5-6 (2016), 365-372.

代表者メールアドレス

梅田純子 umedaj@jwri.osaka-u.ac.jp 